\title{
The Influence of Tofu Pulp Flour Substitution on Protein Content and Acceptability Level of Chicken Nugget
}

\author{
Veni Dayu Putri and Yureya Nita
}

Nursing Program, STIKes Payung Negeri Pekanbaru, Indonesia

\section{Abstract}

This research has been carried out at the Food and Beverage Laboratory of UPT of Testing and Goods Quality Certification (PSMB) of Riau Province from April to September 2018. The purpose of this research was to determine the influence of tofu pulp flour substitution on protein content and determine the panelist acceptability level of chicken nugget produced. The research design used was a Complete Random Design (CRD) with 4 treatments of tofu pulp flour substitution which were $0 \%, 10 \%$, $20 \%$ and $30 \%$ with two replications. Protein content was analyzed by Kjedahl method and panelist acceptability level used organoleptic test. Analysis of protein content

Corresponding Author:

Veni Dayu Putri

venidayu@gmail.com

Received: 18 January 2019

Accepted: 26 February 2019

Published: 12 March 2019

Publishing services provided by Knowledge E

(c) Veni Dayu Putri and Yureya Nita. This article is distributed under the terms of the

Commons Attribution License, which permits unrestricted use and redistribution provided that the original author and source are credited.

Selection and Peer-review under the responsibility of the 1st PANIHC Conference Committee. data was carried out by using the One Way Anova test and level of acceptability used the Kruskal-Wallis test with a level of $5 \%$, respectively. The research result of protein content analysis showed that there was no significant influence of tofu pulp flour substitution on protein content ( $p 0.116>0.05$ ). Organoleptic test result obtained the most preferred chicken nugget was substitution of $10 \%$ tofu pulp flour. Data analysis showed no significant difference between the aroma and the texture of chicken nugget produced $(p>0.05)$. Meanwhile an analysis of the chicken nugget taste showed there was a significant difference $(p<0.05)$ between the two groups of tofu pulp flour, so that the analysis continued with the Man-Whitney test and the result of the group that had a difference in taste was between the tofu pulp flour substitution group with $0 \%$ and $30 \%$ and between groups which tofu pulp flour substitution of $10 \%$ and $30 \%$. Based on the research results, it can be concluded that tofu pulp flour can be used as a substitution in chicken nugget processing without reducing its nutritional value.

Keywords: tofu pulp flour, chicken nugget, protein content, organoleptic test

\section{Introduction}

Tofu pulp flour is one of the waste results of the tofu making process. Some people think that tofu waste is less useful because it includes agricultural product waste that is discarded because it is considered having no economic value, easily damaged and being 
to be used as a medium for bacterial fermentation, because the waste water produced by tofu industry is organic waste that easily broken down by natural microorganisms, so tofu waste can be used for animal feed, organic fertilizers, and even human food (1).

All this time, the utilization of tofu waste as a substituent of processed food is only limited as snacks in the form of "tempe gembus", some of them are used as animal feed or thrown away. If looking of the tofu waste's nutritional value, it still has quite high protein and the fiber contents (2). In food ingredients' list (3), it is mentioned the tofu's nutrient content is actually quite high, containing $26.6 \%$ protein, $18.3 \%$ fat, $41.3 \%$ carbohydrates in $100 \mathrm{~g}$ of dry weight. The tofu waste nutrient content is quite high and the total of it is so many, it gives a big chance for utillized as substituents in food processing such as nugget.

Chicken nugget is one of the innovations in processing poultry-based meat ingredients that are very popular among the people. Chicken nugget is fast food, having nutritional value, and safe for consumption. According to (4) its contained in SNI 016683-2002, nugget is defined as processed product that are printed, cooked, frozen and made from a mixture of ground meat which is coated with or without the addition of other ingredients and is permitted food ingredients. Nugget is very practical, preserved by freezing and nugget can be an alternative side dish and daily snacks. Nugget is generally made from chicken meat. The price of chicken meat as an expensive raw material makes not everyone can enjoy it. With this phenomenon, an alternative processing process is required with tofu waste substitution to reduce the amount of chicken meat usage by not reducing its nutritional value and can reduce production costs. By using tofu waste as substituent in making chicken nugget, the production cost of chicken nugget will become lower and tofu value can be increased (2).

Substitution of tofu pulp flour in making nugget will influence organoleptic characteristics such as aroma, taste and texture so that it will affect the acceptability of nugget. Receiving power test was conducted to determine consumer acceptance of processed chicken nugget products with the aim of assessing the nature or quality of the formula and can produce a preferred product. Based on this description, it is necessary to do research on protein content test and organoleptic quality tests on tofu substituted chicken nugget.

\section{Research Method}




\subsection{Place and time}

This research has been carried out at the Food and Beverage Laboratory of UPT Testing and Goods Quality Certification (PSMB) of Riau Province and at STIKes Payung Negeri Pekanbaru from April to September 2018.

\subsection{Materials and tools}

The materials used were tofu waste from the Garuda Ujung tofu factory and processed into tofu pulp flour by researcher' self, broiler chicken meat, meizena flour, $\mathrm{NaCl}$ salt, garlic, pepper, eggs, bread flour, water and cooking oil. The materials used for protein content analysis were $\mathrm{HgO}, \mathrm{NaOH}$ solvent with $\mathrm{Na} 2 \mathrm{~S} 2 \mathrm{O} 3, \mathrm{HCl}$ solvent, $\mathrm{PP}$ indicator, and aquades water.

The tools used were knife, basin, sieve, meat grinder, scales, baking pan, stove, steaming pot, cauldron, frying pan, LPG gas, plate, plastic packaging, and freezer. The tools used for analyzing were kjedahl heater, pumpkin kjedahl, tools distillation, erlenmeyer, burette, water bath, analytical balance.

\section{Research Design}

The design of this research was a Complete Random Design (CRD) which consisting of four treatments and two replications. The data obtained were analyzed using variance (ANOVA), if the result is significantly difference, so it is followed by a post hoc test at the level of $5 \%$. The treatment is:

$K=100 \%$ Chicken Meat

S10 $=90 \%$ Chicken Meat: $10 \%$ Tofu Pulp Four

S20 $=80 \%$ Chicken Meat: 20\% Tofu Pulp Four

S30 $=70 \%$ Chicken Meat: $30 \%$ Tofu Pulp Four

\section{Research Procedure}

\subsection{Tofu Pulp flour making (5)}

Tofu pulp flour making was started with drying the tofu waste by roasting on low heat for 45-60 minutes or until it was dry. The results obtained were white and clean with smoother grains and produce a distinctive aroma of soybeans. Then the dried tofu dregs 
were blended to get a smaller size. The rough pulp of the tofu pulp flour was sifted to make same the particles.

\subsection{Chicken nugget making (6)}

Firstly, fillet and mill the chicken meat. After that, Mix the milled meat with other ingredients. Then, Stir the ingredients until well blended. Put the dough into a baking dish of a certain thickness. Steam the mixture over medium heat for 20-30 minutes. Afer that, Cut the dough with a size of $3 \mathrm{~cm} \times 1 \mathrm{~cm}$. and then, coat the cut nugget with the beaten eggs and roll the nugget in the bread flour.

\subsection{Protein content test (7)}

Test of protein content on chicken nugget was carried out by using the Kedjedal method.

\subsection{Organoleptic test (8)}

Organoleptic test was done for determining the level of panelists' acceptability for the aroma, taste and texture of chicken nugget. To the panelists, samples were served one by one and asked to rate samples based on their enjoyment according to the scale of values provided. Acceptability scale can be seen in Table 1.

TABLE 1: Acceptability Scale and Numeric Scale.

\begin{tabular}{l|c|}
\hline Acceptability Scale & Numeric Scale \\
\hline Absolutely like & 5 \\
\hline Very like & 4 \\
\hline like & 3 \\
\hline Like enough & 2 \\
\hline Unlike & 1
\end{tabular}

\section{Result and Discussion}

\subsection{Protein content test}

The result of ANOVA statistical test on protein content of chicken nugget showed that the treatment of tofu pulp flour substitution was not significant $(p>0.05)$. From Table 2 , 
TABLE 2: Protein Content Test's Results on Chicken Nugget from Tofu pulp flour Substitution.

\begin{tabular}{|c|c|}
\hline Tofu Pulp Flour Substitution & Protein (\%) \\
\hline $0 \%$ & 14,72 \\
\hline $10 \%$ & 10,23 \\
\hline $20 \%$ & 11,34 \\
\hline $30 \%$ & 11,37 \\
\hline
\end{tabular}

it can be seen that the more addition of tofu pulp flour used in making chicken nugget, the higher protein content in the nugget.

\subsection{Protein content}

From table 2, it can be seen that the protein content produced in chicken nugget was around $10.23 \%-14.72 \%$. The treatment of $0 \%$ tofu pulp flour substitution has higher protein content than the other tofu pulp flour substitution treatment which was $14.72 \%$. According to (9) broiler chicken meat contains $21 \%$ protein, higher than the protein content in tofu pulp flour $17.72 \%(10)$, so that in chicken nugget with $0 \%$ tofu pulp flour substitution was higher protein content compared to substitution of others tofu pulp flour known. Protein content for chicken nugget with 10\%, 20\% and 30\% tofu pulp flour substitution was below the minimum limit of SNI 01-6683-2002, which was $12 \%$. Chicken nugget closing to the level of SNI standard protein was chicken nugget with $30 \%$ tofu pulp flour substitution with a value of $11.37 \%$. According to (11) protein content which still did not meet the SNI standard can be influenced by several factors, the possibility of protein denaturation occurring during the process of making nugget. Protein denaturation can be done in various ways, namely heat, $\mathrm{pH}$, chemicals, mechanics, and so on. In this case denaturation can result from heat during the grinding and cooking process.

Based on the ANOVA test result ( $p$ value 0.116 ), it can be concluded that there was no significant influence of the tofu pulp flour substitution on protein content in chicken nugget.

\subsection{Organoleptic test}

Organoleptic test was carried out to determine the quality of a food ingredient. Factors that influence the acceptance of a food were taste stimulation such as aroma, taste and texture (2). The results of organoleptic test of 15 panelists showed results as presented in table 3. 
TABLE 3: Results of Organoleptic Tests on Chicken Nugget of Tofu Pulp Flour Substitution.

Assessment criteria
Aroma
Taste
Texture
Average Score

\begin{tabular}{|c|}
\hline S\% \\
\hline 3.47 \\
\hline 3.20 \\
\hline 3.03 \\
\hline 3.23 \\
\hline
\end{tabular}

Substitution of Tofu Pulp Flour

\begin{tabular}{|l|l|l|}
\hline $10 \%$ & $20 \%$ & $30 \%$ \\
\hline 3.30 & 3.07 & 3.00 \\
\hline 2.93 & 2.60 & 2.03 \\
\hline 2.83 & 2.80 & 2.73 \\
\hline 3.02 & 2.82 & 2.58 \\
\hline
\end{tabular}

From four criteria of chicken nugget with various substitutes, tofu pulp flour was the highest score about 3.02 for chicken nugget with $10 \%$ tofu pulp flour substitution which was close to chicken nugget without tofu pulp flour about 3.23, while the lowest value for meatballs with $30 \%$ Tofu pulp was obtained a mean value of 2.58 so that among the three substitutes of tofu pulp flour, the most preferred was chicken nugget with $10 \%$ tofu flour substitution.

The results of statistical analysis with Kruskal-Wallis for organoleptic assessment showed that there was a quality effect of chicken nugget from the taste aspect ( $p$ value $0.00)$, whereas there was no effect from the aspect of aroma and texture ( $p>0.05)$.

\subsection{Aroma}

Aroma is an indicator that can be recognized by the sense of smell, namely the nose. The smell of food can determine the delicacy of the food ingredients (12). The panelists' assessment results on the aroma indicator showed the highest value obtained by chicken nugget with $10 \%$ tofu pulp flour subtitution having typical nugget fragrant criteria getting an average value of 3.30. According to (13) the tofu pulp flour produced still had the typical aroma of tofu waste (langu). Tofu dreg contained a distinctive aroma of soybeans that smells bad or musty, so that if the more addition of tofu pulp, so the identification of the distinctive aroma of tofu dregs was higher. From table 3 , it can be seen that chicken nugget with $30 \%$ tofu pulp flour substitution (the highest substitution of tofu flour) had the lowest average aroma value of 3.00.

Aroma assessment was a subjective evaluation that required a sensitivity of sensing and smelling. The cooking process played an important role in this case because when cooking chicken nugget' fat will produce volatile components raising the aroma of chicken nugget. By doing a cooking, volatile compounds will arise which will produce a unique flavor and aroma of cooked meat (14).

The result of the statistical analysis on the aroma aspect of chicken nugget obtained by Kruskal Wallis $(\mathrm{H})$ value was 3.223 with the mean value of the tofu pulp flour tofu 
substitution group at $10 \%$ at $26.90 ; 20 \%$ substitution group of $31.73 ; 30 \%$ substitution group was 26.97 and 0\% substitution group (control) was 36.40. From the Kruskal Wallis test result obtained $p$ value 0.358 so it can be concluded that there was no significant difference of the chicken nugget's aroma to the tofu pulp flour substitution.

\subsection{Taste}

Taste is an important factor in the acceptance of a food product and as part of an organoleptic test. From table 3 , the results obtained for the taste indicator of the highest mean value was found in chicken nugget with $10 \%$ tofu pulp flour substitution at 2.93 . The flavor on chicken nugget was also influenced by chicken meat added, cooking method, especially the high temperature and cooking time, and seasoning. Seasoning played an important role in the formation of chicken nugget (15).

The results of the Kruskal Wallis analysis showed that there were differences in chicken nugget that were statistically significant ( $p<0.05$ ) between $0 \%, 10 \%, 20 \%$ and $30 \%$ tofu pulp flour substitution groups and $10 \%$ tofu pulp flour substitution group of 36,$77 ; 20 \%$ substitution group of $27.70 ; 30 \%$ substitution group of 15.97 ; and the $0 \%$ substitution group (control group) was 41.57 . With the increasing Kruskal Wallis $(\mathrm{H})$ value, the greater the difference between groups was compared. To determine which groups differed significantly in the chicken nugget, then a follow-up test (post hoc test) was carried out by performing repeated Mann-Whitney tests between: $0 \%$ substitution group with 10\%; 0\% substitution group with 20\%; 0\% substitution group with $30 \%$; $10 \%$ substitution group with $20 \%$; $10 \%$ substitution group with $30 \%$; and a $20 \%$ substitution group with $30 \%$.

TABLE 4: Post Hoc Analysis of the Chicken Nugget Taste with Mann-Whitney Test between groups of Tofu pulp flour Substitutes.

\begin{tabular}{|l|c|c|c|}
\hline Substitution of Tofu Pulp Flour & Mann-Whitney U & N & P \\
\hline 0\% and 10\% & 85,000 & 15 & 0,228 \\
\hline 0\% and 20\% & 64,500 & 15 & 0,042 \\
\hline 0\% and 30\% & 22,000 & 15 & 0,000 \\
\hline $10 \%$ and 20\% & 76,500 & 15 & 0,123 \\
\hline $10 \%$ and 30\% & 27,00 & 15 & 0,000 \\
\hline $20 \%$ and 30\% & 70,500 & 15 & 0,075 \\
\hline
\end{tabular}

Table 4 was the result of post hoc analysis of chicken nugget flavor, and it can be concluded that the tofu pulp flour substitution group which had a significant difference in the taste of chicken nugget was between $0 \%$ and $30 \%$ tofu pulp flour substitution group (control) and between $10 \%$ and $30 \%$ tofu pulp flour substitution group, while between 
the substitution groups $0 \%$ and $10 \%, 0 \%$ and for $20 \%, 10 \%$ and $20 \%, 20 \%$ and $30 \%$ tofu pulp flour substitution groups, there was no difference in the taste of chicken nugget.

From the values of panelists' preference for chicken nugget flavor presented in Table 3 showed the highest value of panelists' preference for chicken nugget flavor was in the lowest substitution of tofu pulp flour (10\% substitution). The flavor value of the chicken nugget produced will decrease as the amount of flour that was added to the mixture.

\subsection{Texture}

The texture of a food ingredient greatly influenced the taste of the food. A good texture will support the taste of a food ingredient (16). Based on the results of organoleptic tests in Table 3, the results of the panelists' assessment on the texture indicator with the highest value was obtained by chicken nugget with $10 \%$ tofu pulp flour substitution about 2.83. Texture of chicken nugget with tofu pulp substitution was softer than the control group. According to (2) one of the factors influencing the texture of chicken nugget was the relatively high tofu fresh water content and low starch constituent amylose amyloppectin content. The amylose content of the tofu waste played a role in gel formation (the gelatinization process) which will determine the texture of the final product.

The resulting chicken nugget texture was influenced by the substitution of tofu pulp flour. By increasing the substitution of tofu pulp flour will affect the nugget texture to be rough because of to the fiber content of tofu pulp flour (17). The milling process may also affect the texture of nugget. Milled chicken meat texture was different from the texture of whole chicken meat. This was because during the grinding process it was suspected that there was a termination of muscle fibers by a grinding tool, so that it affected the texture of the ground chicken. The grinding or reducing the size of the chicken served to expand the surface area of the chicken, so that protein extraction can occur. Protein extraction was very important because if no extraction occured, chicken meat cannot be fused when cooked, and this can affect the texture of the chicken nugget produced.

The texture of substituted chicken nugget with tofu pulp flour was also thought to be influenced by the use of added binder. (18), stating that binder was a material used in food to bind the water contained in the mixture. The function of the binder improved the stability of the emulsion, decreased shrinkage due to cooking, gave a bright color, increased the elasticity of the product, formed a dense texture and drawed water in the mixture. Generally binder added to food dough was starchy ingredients such as tapioca flour, flour rice, meizena flour, sago flour and wheat flour. In this study the binding material used was meizena flour. 
Kruskal Wallis test result obtained $p$ value about 0.621 , hence, that it can be concluded that there was no significant difference in chicken nugget texture to tofu pulp flour substitution.

\section{Conclusion}

From the research results, it can be concluded that the substitution of tofu pulp flour did not influence the increase of protein content of chicken nugget produced. Substitution of $10 \%$ tofu pulp flour on chicken nugget produced the best physical characteristics and acceptance level of panelists (acceptability) which were most preferred in terms of aroma, taste and texture.

\section{Acknowledgment}

The researcher thanks to the Director of Research and Community Service (DRPM) of the Directorate General of Higher Education of the Republic of Indonesia who has funded all activities in this research, Head of the Higher Education Service Institution (LLDIKTI) Region X, Chairperson of STIKes Payung Negeri Pekanbaru who has given permission to implement the tri Dharma Perguruan Tinggi, Chairperson of the Institute for Research and Community Service (LPPM) STIKes Payung Negeri Pekanbaru and Head of the Riau Province's Cooperative, Small and Medium Enterprise and Trade Office which has facilitated the process of carrying out this research.

\section{References}

[1] Anggraeni, Hasibuan S, Malik B, Wijaya R. Improving The Quality of Tofu Waste as A Source of Feed Through Fermentation Using the Bacillus amyloliquefaciens Culture. Int J Adv Sci Eng Inf Technol [Internet]. 2013;3(4):285-8. Available from: http://ijaseit.insightsociety.org/index.php?option\$=\$com_content\{\&\}view\$= \$article $\{\&\}$ id $\$=\$ 9\{\&\}$ temid $\$=\$ 1\{\&\}$ article_id $\$=\$ 305$

[2] Handarsari E, Syamsianah A, lii PD, Fikkes G. Analisis Kadar Zat Gizi, Uji Cemaran Logam Dan Organoleptik Pada Bakso Dengan Substituen Ampas Tahu. Pros Semin Nas Unimus. 2010;245-51.

[3] Direktorat Gizi Depkes RI. Daftar Komposisi Bahan Makanan. Jakarta; 2015.

[4] BSN. SNI 01-6683-2002?: Nugget Ayam. Jakarta; 2002. 
[5] Fara DNT. Pemanfaatan Tepung Ampas Tahu Pada Pembuatan Produk Cookies (Chocolate Cookies, Bulan Sabit Cookies, dan Pie Lemon Cookies). Universitas Negeri Yogyakarta; 2012.

[6] Azima F, Ismed. Penuntun Praktikum Teknologi Hasil Hewani. Universitas Andalas. Padang; 2012.

[7] Association of Official Analytical Chemist (AOAC). Official Methods of Analysis. 18th ed. USA: Association of Official Analytical Chemist Inc. Mayland. USA; 2005.

[8] Agusman. Pengujian Organoleptik. Modul Penanganan Mutu Fisis (Organoleptik). Universitas Muhammadiyah Semarang; 2013.

[9] Soeparno. IImu dan Teknologi Daging. Yogyakarta: Gadjah Mada Universitas Press.; 1994.

[10] Rachmawati S, Kurnia P. Pembuatan Kecap dan Cookies Ampas Tahu sebagai Upaya Peningkatan Potensi Masyarakat di Sentra Industri Tahu, Kampung Krajan, Mojosongo, Surakarta. Warta?: 12(1). 2009;1-2.

[11] Inarest A, Fathonah S, Rosidah. Pengaruh Penggunaan Jenis Sumber Protein dan Jenis Filler yang Berbeda dalam Pembuatan Nuggets Ampas Tahu. Food Sci Culin Educ J. 2014;3(1):56-62.

[12] Winarno, F.G. Kimia Pangan dan Gizi. Gramedia; 2004.

[13] Sulaiman T, Syahrumsyah H. Formulasi Tepung Ampas Tahu dan Terigu Terhadap Mutu Stik. J Teknol Pertan Univ Mulawarman. 2014;9(2):59-64.

[14] Soeparno. Ilmu dan Teknologi Daging. Gadjah Mada University Press. Yogyakarta; 2005.

[15] Wulandari E, Suryaningsih L, Pratama A, Putra DS, Runtini N. Karakteristik Fisik , Kimia dan Nilai Kesukaan Nugget Ayam Dengan Penambahan Pasta Tomat. J IImu Ternak. 2016;16(2):95-9.

[16] Suryatmoko. Kajian Penambahan Tepung Tapioka dan Susu Skim Terhadap Penerimaan Konsumen Pada Produk Nugget Ikan Mas. Vol. 1. Unisla; 2010.

[17] Permadi SN, Mulyani S, Hintono A. Kadar Serat, Sifat Organoleptik, dan Rendemen Nugget Ayam Yang Disubstitusi dengan Jamur Tiram Putih (Plerotus ostreatus). J Apl Teknol Pangan. 2012;1(4):115-20.

[18] Anjarsari B. Pangan Hewani Fisiologi Pasca Mortem dan Teknologi. Graha IImu, Yogyakarta; 2010. 